\title{
Systolic and Diastolic Function in Congestive Heart Failure Pediatric Patients
}

\author{
ANGELA BUTNARIU ${ }^{1}$, CAMELIA ZAMFIR ${ }^{2}$, MIHAELA IANCU ${ }^{3}$, \\ DANIELA IACOB ${ }^{1}$, G. SAMASCA ${ }^{4}$, IULIA LUPAN ${ }^{5}$ \\ ${ }^{1}$ Department of Pediatrics III, "Iuliu Hațieganu" University of Medicine and Pharmacy Cluj-Napoca, Romania \\ ${ }^{2}$ Heart Institute Cluj-Napoca, Romania \\ ${ }^{3}$ Department of Bioinformatics, "Iuliu Haţieganu" University of Medicine and Pharmacy Cluj-Napoca, Romania \\ ${ }^{4}$ Department of Immunology, "Iuliu Hațieganu" University of Medicine and Pharmacy Cluj-Napoca, Romania \\ ${ }^{5}$ Department of Molecular Biology and Biotechnology, "Babeş-Bolyai” University, Cluj-Napoca, Romania
}

\begin{abstract}
Background and Aims. Two-dimensional (2D) and Doppler echocardiography are the main methods for the non-invasive evaluation of ventricular function in children. Our study monitored the evaluation of systolic and diastolic function in pediatric patients, using classical echocardiographic parameters and pulsed tissue Doppler parameters, as well as the correlation between these.

Methods. The study included 18 healthy children and 9 children diagnosed with congestive heart failure secondary to congenital heart malformations. The parameters of systolic and diastolic function were measured by 2D echocardiography, 2D guided $\mathrm{M}$ mode, color and pulsed Doppler, as well as by pulsed tissue Doppler at the level of the mitral and tricuspid annulus.

Results. A relaxation alteration pattern or a pseudonormal pattern of $\mathrm{E}$ diastolic velocity compared to the A wave was found $(\mathrm{E}=\mathrm{A} ; \mathrm{E}>\mathrm{A})$ in the group of subjects with heart failure. $\mathrm{E}$ wave deceleration time had significantly increased values in the case of patients with $\mathrm{CHF}$, being correlated with diastolic dysfunction. Left ventricular flow propagation velocity $\mathrm{Vp}$ was decreased in patients with heart failure, the $\mathrm{E} / \mathrm{Vp}$ ratio being maintained relatively constant in subjects with congestive heart failure and healthy subjects, most probably on account of the concomitant change in the E wave. Associations between the severity of systolic dysfunction and the diastolic dysfunction were found in pediatric patients diagnosed with congestive heart failure (Student test, $\mathrm{p}<0.05$ ).

Conclusions. Tissue Doppler measurements proved to be useful for the evaluation of pediatric patients with altered ventricular geometry secondary to congenital heart disease, systolic-diastolic dysfunction and heart failure.
\end{abstract}

Key words: evaluation, echocardiographic parameters, ventricular function, children, congestive heart failure.

\section{INTRODUCTION}

Two-dimensional (2D) and Doppler echocardiography are techniques for the measurement of the global function as well as of the regional ventricular function. Parameters of the systolic function such as the ejection fraction, the shortening fraction and myocardial deformation indicate changes in the ventricular size, while $\mathrm{dP} / \mathrm{dt}$, the myocardial performance index and tissue velocities are based on Doppler techniques. The most frequently used echocardiographic parameters in clinical practice for the study of the global left ventricular (LV) systolic function are the shortening fraction and the ejection fraction, most frequently determined by two-dimensional echocardiography and 2D guided $M$ mode [1]. Another indicator of the longitudinal and global systolic function, with prognostic value, is represented by the mitral annular plane systolic excursion (MAPSE) [2].
The diastolic ventricular function was less understood in the past, being more rarely evaluated in pediatric pathology. The interest in this field has progressively increased. The increase in LV filling pressures represents the final common pathway to heart failure. For this reason, the evaluation of LV diastolic function is an important stage in the diagnosis, the monitoring of therapy and the evaluation of prognosis in heart failure. Over the past years, Doppler echocardiography has demonstrated its usefulness in the non-invasive evaluation of the LV diastolic function, being an easily accessible method. At present, the majority of the information related to LV protodiastole is derived from the Doppler evaluation of the transmitral and transvenous pulmonary flow [3].

The left ventricular flow propagation velocity from the annulus toward the apex in diastole $(\mathrm{Vp})$ using color Doppler is another indicator of ventricular relaxation. Studies have shown that $\mathrm{Vp}$ is 
relatively independent of preload, being influenced in the highest proportion by left ventricular relaxation [4]. Over the past years, a particular interest in the evaluation of right ventricular diastolic function has also been noted. Right ventricular filling can be assessed similarly to left ventricular filling by Doppler echocardiography, by calculating the tricuspid flow and systemic venous flow indices. Their calculation can be limited by preload changes and intrathoracic pressure changes with respiration. In the case of systemic venous flow velocities, their age independence was noted compared to other Doppler parameters. The Doppler systemic venous flow pattern is influenced by arterial hypertension, tricuspid valvular dysfunction, pericardial diseases and cardiac arrhythmias [5]. A complementary method to the standard method for the evaluation of diastolic ventricular function is the measurement of myocardial velocities by pulsed tissue Doppler.

Although in adults it is already well implemented in clinical practice, in children this method is still at an early stage. However, an increasing number of publications in the field evidence the importance of TDI parameters in the evaluation of diastolic function in children. The reference values of TDI velocities in healthy children were published by Eidem et al. in 2004 [6]. Tissue Doppler imaging is little used in pediatrics and physiological norms have not been established in children. However, the few published studies consider that tissue Doppler imaging is feasible in pediatric cardiology.

TDI velocities can be measured by both pulsed Doppler and color Doppler, allowing the evaluation of systolic and diastolic function. Pulsed Doppler velocities are approximately $20 \%$ higher than color Doppler velocities [7]. In the case of the analysis of longitudinal and radial myocardial function, velocities are higher at the base of the heart and at endocardial level, decreasing progressively towards the apex, the epicardium, respectively. Diastolic ventricular function is determined by the evaluation of the longitudinal movement at the level of the mitral, tricuspid and septal annulus, with the calculation of early and late diastolic velocities (2 negative waves: Ea or E'; Aa or A' respectively $[8,9]$. TDI diastolic velocities at both the mitral and tricuspid annulus represent a marker of ventricular relaxation, being relatively independent of ventricular geometry and preload, unlike transmitral and transtricuspid flow parameters [10-13].
In children, TDI velocities vary with age, heart rate, the myocardial layer and region, and cardiac growth (telediastolic dimension and left ventricular mass) [14]. In pediatric pathology, the main causes of congestive heart failure (CHF) are represented by congenital heart disease. In these cases, ventricular geometry, predominantly right ventricular geometry, can be deeply altered. The standard parameters for the evaluation of ventricular function lack accuracy in these situations, TDI velocities becoming indicators with a superior value due to their relative independence in relation to ventricular geometry [15].

\section{AIM OF THE STUDY}

The aim of the study was the evaluation of systolic and diastolic function measured by conventional echocardiographic methods as well as by pulsed tissue Doppler parameters, with the presentation of some study features in healthy pediatric patients and in patients diagnosed with $\mathrm{CHF}$ secondary to congenital heart malformations.

\section{MATERIAL AND METHOD}

\section{PATIENTS}

This study included 27 pediatric patients, divided into: group 1, the control group, including 18 patients with a normal LV ejection fraction, and group 2, formed by 9 patients diagnosed with $\mathrm{CHF}$ NYHA III, IV, with an impaired LV ejection fraction. The group of patients with CHF included patients with congenital heart malformation with a recent history of at least one echocardiographic examination certifying the cause of heart failure.

\section{METHODS}

The systolic and diastolic function parameters were measured by $2 \mathrm{D}$ echocardiography, $\mathrm{M}$ mode, color and pulsed Doppler, as well as by pulsed tissue Doppler at the level of the mitral and tricuspid annulus.

- LV systolic function was evaluated

a) by the $2 D$ method and $2 D$ guided $M$ mode, determining the following parameters:

- left ventricular volumes and ejection fraction (LVEF) by the monoplane ellipsoid method in 4 chamber apical section; 
- mitral and tricuspid annular plane systolic excursion (MAPSE, TAPSE);

b) by the tissue Doppler method, determining the following parameters:

- the maximal systolic velocity at the level of the septal and lateral mitral annulus and lateral tricuspid annulus, by tissue Doppler (S'), in 4 chamber apical section.

- LV diastolic function was evaluated

a) by the Doppler method, determining the following parameters:

- the maximal velocity of early diastolic filling (E), the maximal velocity of late diastolic filling by atrial contraction (A) and the E/A ratio;

- the E wave deceleration time (EDT), the duration of ventricular filling by atrial contraction measured at the level of the mitral annulus (Adur),

b) by the tissue Doppler method, determining the following parameters:

- the maximal early (E') and late diastolic velocity by atrial contraction (A') at the lateral and septal mitral annulus and at the lateral tricuspid annulus in 4 chamber apical plane, E'/A' ratio;

c) by color $M$ mode, determining the following parameters:

- the LV flow propagation velocity from the annulus towards the apex in diastole $(\mathrm{Vp})$.

\section{RESULTS}

- Comparative analyses of E and A transmitral flow velocities, of mitral and tricuspid annular plane systolic excursion, as well as of LV flow propagation velocity $\mathrm{Vp}$ were performed in both groups (Tables 1,2). The Student test shows statistically significant differences in $\mathrm{E}$ values between the two groups $(p<0.001)$. The Student test shows statistically significant differences in EDT between the two groups $(\mathrm{p}=0.01<0.05)$ (Table 3). The statistical analysis of $\mathrm{Vp}$ values evidences significant differences in $\mathrm{Vp}$ between the groups $(\mathrm{p}<0.001)$.

A synthesis of the results of the above statistical calculations evidences a relaxation alteration pattern or a pseudonormal pattern of E diastolic velocity compared to the $\mathrm{A}$ wave $(\mathrm{E}=\mathrm{A}$; $\mathrm{E}>\mathrm{A}$ ) in the group of subjects with CHF compared to the control group. The $\mathrm{E}$ wave deceleration time, EDT, had significantly higher values in patients of the CHF group, correlating with diastolic dysfunction present in patients with CHF. Vp was decreased in patients of the CHF group (Table 4), the $\mathrm{E} / \mathrm{Vp}$ ratio being maintained relatively constant between the two groups, most probably on account of the concomitant alteration of the $\mathrm{E}$ wave. In the case of the mitral and tricuspid annular plane systolic excursion (MAPSE, TAPSE), there were no significant changes between the two groups of patients.

- The tissue velocities obtained by pulsed Doppler E', A', S' at the 3 levels: lateral mitral annulus (lat), septal mitral annulus (sep), tricuspid annulus (dr) were also compared in healthy patients with normal LVEF and in patients with CHF, with impaired systolic function (Tables 5, 6). A significant decrease, Student test, $p<0.05$ (Table 7), was found in tissue velocities both at the lateral and septal mitral annulus (except for A' sep), as well as at the lateral tricuspid annulus (except for $A^{\prime}$ dr), in patients with cardiac dysfunction of the CHF group compared to the control group.

Table 1

Mean values of the diastolic velocities of transmitral flow, of LV flow propagation velocity, E/A and E/Vp ratio, E wave deceleration time EDT, mitral and tricuspid annular plane systolic excursion MAPSE and TAPSE

\begin{tabular}{|l|c|c|}
\hline & Control group (normal LVEF) & Group with CHF (low LVEF) \\
\hline $\mathrm{E}(\mathrm{m} / \mathrm{s})$ & $0.83+/-0.1$ & $0.48+/-0.09$ \\
\hline $\mathrm{A}(\mathrm{m} / \mathrm{s})$ & $0.45+/-0.08$ & $0.46+/-0.26$ \\
\hline $\mathrm{E} / \mathrm{A}$ & $1.88+/-0.29$ & $1.77+/-0.98$ \\
\hline $\mathrm{Vp}(\mathrm{cm} / \mathrm{s})$ & $97.15+/-17.37$ & $59.33+/-12.67$ \\
\hline $\mathrm{E} / \mathrm{Vp}$ & $0.89+/-0.19$ & $0.82+/-0.09$ \\
\hline EDT $(\mathrm{ms})$ & $157.78+/-16.91$ & $210+/-30.12$ \\
\hline MAPSE $(\mathrm{mm})$ & $12.94+/-1.17$ & $13.5+/-2.33$ \\
\hline TAPSE $(\mathrm{mm})$ & $18.44+/-1.79$ & $18.11+/-1.46$ \\
\hline
\end{tabular}


Table 2

Comparisons between the groups - Values of the diastolic velocities of transmitral flow, of LV flow propagation velocity,

$\mathrm{E} / \mathrm{A}$ and $\mathrm{E} / \mathrm{Vp}$ ratio, $\mathrm{E}$ wave deceleration time EDT, mitral and tricuspid annular plane systolic excursion MAPSE and TAPSE

\begin{tabular}{|c|c|c|c|c|c|c|c|c|c|}
\hline \multicolumn{10}{|c|}{ Descriptive parameters } \\
\hline & & \multirow{2}{*}{$\mathbf{N}$} & \multirow{2}{*}{ Mean } & \multirow{2}{*}{$\begin{array}{c}\text { Std. } \\
\text { Deviation }\end{array}$} & \multirow{2}{*}{$\begin{array}{l}\text { Std. } \\
\text { Error }\end{array}$} & \multicolumn{2}{|c|}{$\begin{array}{c}\text { 95\% Mean Confidence } \\
\text { Interval }\end{array}$} & \multirow{2}{*}{ Minimum } & \multirow{2}{*}{ Maximum } \\
\hline & & & & & & $\begin{array}{l}\text { Lower } \\
\text { Bound }\end{array}$ & Upper Bound & & \\
\hline \multirow{3}{*}{$\mathrm{E}$} & C.G. & 18 & 0.83 & 0.11 & 0.03 & 0.77 & 0.89 & 0.65 & 1.01 \\
\hline & S.G. & 9 & 0.48 & 0.11 & 0.04 & 0.39 & 0.56 & 0.35 & 0.66 \\
\hline & Total & 27 & 0.71 & 0.20 & 0.04 & 0.63 & 0.79 & 0.35 & 1.01 \\
\hline \multirow{3}{*}{ A } & C.G. & 18 & 0.45 & 0.10 & 0.02 & 0.40 & 0.50 & 0.26 & 0.6 \\
\hline & S.G. & 9 & 0.46 & 0.31 & 0.10 & 0.22 & 0.69 & 0.07 & 0.9 \\
\hline & Total & 27 & 0.45 & 0.19 & 0.04 & 0.38 & 0.53 & 0.07 & 0.9 \\
\hline \multirow{3}{*}{$\mathrm{E} / \mathrm{A}$} & C.G. & 18 & 1.88 & 0.38 & 0.09 & 1.68 & 2.07 & 1.3 & 2.9 \\
\hline & S.G. & 9 & 1.77 & 1.43 & 0.48 & 0.67 & 2.87 & 0.4 & 5 \\
\hline & Total & 27 & 1.84 & 0.85 & 0.16 & 1.50 & 2.18 & 0.4 & 5 \\
\hline \multirow{3}{*}{$\mathrm{E} / \mathrm{Vp}$} & C.G. & 18 & 0.89 & 0.23 & 0.05 & 0.77 & 1.01 & 0.53 & 1.38 \\
\hline & S.G. & 9 & 0.82 & 0.11 & 0.04 & 0.73 & 0.91 & 0.6 & 0.95 \\
\hline & Total & 27 & 0.87 & 0.20 & 0.04 & 0.79 & 0.95 & 0.53 & 1.38 \\
\hline \multirow{3}{*}{ MAPSE } & C.G. & 18 & 12.94 & 1.39 & 0.33 & 12.25 & 13.64 & 11 & 15 \\
\hline & S.G. & 9 & 13.50 & 2.96 & 0.99 & 11.23 & 15.77 & 9.5 & 18 \\
\hline & Total & 27 & 13.13 & 2.01 & 0.39 & 12.34 & 13.92 & 9.5 & 18 \\
\hline \multirow{3}{*}{ TAPSE } & C.G. & 18 & 18.44 & 2.15 & 0.51 & 17.38 & 19.51 & 15 & 21 \\
\hline & S.G. & 9 & 18.11 & 2.03 & 0.68 & 16.55 & 19.67 & 14 & 20 \\
\hline & Total & 27 & 18.33 & 2.08 & 0.40 & 17.51 & 19.15 & 14 & 21 \\
\hline \multirow{3}{*}{ EDT } & C.G. & 18 & 157.78 & 20.74 & 4.89 & 147.47 & 168.09 & 130 & 200 \\
\hline & S.G. & 9 & 201.11 & 36.21 & 12.07 & 173.28 & 228.94 & 140 & 250 \\
\hline & Total & 27 & 172.22 & 33.44 & 6.43 & 159.00 & 185.45 & 130 & 250 \\
\hline
\end{tabular}

Legend: C.G. = control group; S.G. = group of subjects with CHF.

Table 3

Student test for the analysis of E, A, E/A, E/Vp, MAPSE, TAPSE and EDT

\begin{tabular}{|c|c|c|c|c|c|c|c|c|c|c|}
\hline \multicolumn{11}{|c|}{ Independent groups } \\
\hline & & \multicolumn{2}{|c|}{$\begin{array}{c}\text { Levene's test } \\
\text { for the equality of } \\
\text { variances }\end{array}$} & \multicolumn{7}{|c|}{ t-test for the equality of means } \\
\hline & & \multirow{2}{*}{$\mathbf{F}$} & \multirow{2}{*}{$\mathbf{P}$} & \multirow{2}{*}{$\mathbf{t}$} & \multirow{2}{*}{ Df } & \multirow{2}{*}{$\mathbf{P}$} & \multirow{2}{*}{ M.D. } & \multirow{2}{*}{$\begin{array}{l}\text { S.E. } \\
\text { M.D. }\end{array}$} & \multicolumn{2}{|c|}{$\begin{array}{l}\text { 95\% difference confidence } \\
\text { interval }\end{array}$} \\
\hline & & & & & & & & & $\begin{array}{l}\text { Lower } \\
\text { bound }\end{array}$ & $\begin{array}{l}\text { Upper } \\
\text { bound }\end{array}$ \\
\hline $\mathrm{E}$ & $\begin{array}{l}\text { Equal } \\
\text { variances }\end{array}$ & 0.03 & 0.86 & 7.74 & 25.00 & $<0.01$ & 0.35 & 0.05 & 0.26 & 0.45 \\
\hline A & $\begin{array}{l}\text { Unequal } \\
\text { variances }\end{array}$ & 25.15 & 0.00 & -0.02 & 8.83 & 0.99 & 0.00 & 0.11 & -0.24 & 0.24 \\
\hline $\mathrm{E} / \mathrm{A}$ & $\begin{array}{l}\text { Unequal } \\
\text { variances }\end{array}$ & 8.41 & 0.01 & 0.22 & 8.58 & 0.83 & 0.11 & 0.49 & -1.00 & 1.21 \\
\hline $\mathrm{E} / \mathrm{Vp}$ & $\begin{array}{l}\text { Equal } \\
\text { variances }\end{array}$ & 4.26 & 0.05 & 0.81 & 25.00 & 0.42 & 0.07 & 0.08 & -0.10 & 0.24 \\
\hline MAPSE & $\begin{array}{l}\text { Unequal } \\
\text { variances }\end{array}$ & 6.92 & 0.01 & -0.53 & 9.81 & 0.60 & -0.56 & 1.04 & -2.88 & 1.77 \\
\hline TAPSE & $\begin{array}{l}\text { Equal } \\
\text { variances }\end{array}$ & 0.48 & 0.49 & 0.39 & 25.00 & 0.70 & 0.33 & 0.86 & -1.44 & 2.11 \\
\hline EDT & $\begin{array}{l}\text { Unequal } \\
\text { variances }\end{array}$ & 5.84 & 0.02 & -3.33 & 10.70 & 0.01 & -43.33 & 13.02 & -72.09 & -14.58 \\
\hline
\end{tabular}

Legend: M.D. = mean of differences; S.E. $=$ standard error. 
Table 4

LV flow propagation velocity from the annulus to the apex in diastole $(\mathrm{Vp})$ - comparisons between the groups

\begin{tabular}{|c|c|c|c|c|c|c|c|c|}
\hline $\mathbf{V p}$ & $\begin{array}{c}\text { No. of } \\
\text { subjects }\end{array}$ & Mean & $\begin{array}{l}\text { Standard } \\
\text { deviation }\end{array}$ & Minimum & $\begin{array}{c}1^{\text {st }} \\
\text { quartile }\end{array}$ & $\begin{array}{c}2^{\text {nd }} \text { quartile }= \\
\text { Median }\end{array}$ & $\begin{array}{c}3^{\text {rd }} \\
\text { quartile }\end{array}$ & Maximum \\
\hline Control group & 18 & 97.15 & 23.03 & 65.00 & 82.00 & 95.30 & 109.50 & 150.00 \\
\hline Group with CHF & 9 & 59.33 & 20.62 & 41.00 & 46.00 & 58.00 & 61.00 & 110.00 \\
\hline Total & 27 & 84.54 & 28.42 & 41.00 & 62.50 & 86.00 & 100.00 & 150.00 \\
\hline
\end{tabular}

Table 5

Comparative mean values of tissue velocities in the control group and the study group; E'sep, A'sep, S'sep - E', A', S' velocities at the septal mitral annulus; E' lat, $A^{\prime}$ lat, $S^{\prime}$ lat - E', $A^{\prime}, S^{\prime}$ velocities at the lateral mitral annulus; E'dr, A'dr, S'dr-E', A', S' velocities at the tricuspid annulus

\begin{tabular}{|l|c|c|}
\hline & Control group (normal LVEF) & Group with CHF (low LVEF) \\
\hline E'sep $(\mathrm{cm} / \mathrm{s})$ & $-12.97+/-1.76$ & $-7.51+/-2.65$ \\
\hline A'sep $(\mathrm{cm} / \mathrm{s})$ & $-5.78+/-1.34$ & $-6.23+/-0.47$ \\
\hline S'sep $(\mathrm{cm} / \mathrm{s})$ & $8.38+/-0.81$ & $6.79+/-0.32$ \\
\hline E'lat $(\mathrm{cm} / \mathrm{s})$ & $-16.97+/-2.85$ & $-10.12+/-0.92$ \\
\hline A'lat $(\mathrm{cm} / \mathrm{s})$ & $-5.75+/-1.14$ & $-4.8+/-0.33$ \\
\hline S'lat $\left.^{\prime} \mathrm{cm} / \mathrm{s}\right)$ & $9.93+/-2.18$ & $7.73+/-0.48$ \\
\hline E'dr $(\mathrm{cm} / \mathrm{s})$ & $-12.83+/-1.44$ & $-8.97+/-0.64$ \\
\hline A'dr $(\mathrm{cm} / \mathrm{s})$ & $-8.07+/-1.14$ & $-8.07+/-1.37$ \\
\hline S'dr $\left.^{\prime} \mathrm{cm} / \mathrm{s}\right)$ & $12.23+/-2$ & $8.91+/-1.83$ \\
\hline
\end{tabular}

Legend: TDI velocities are noted by + (plus) or - (minus) depending on the direction in which myocardial fibers move during the two phases of the cardiac cycle.

Table 6

Comparisons between the groups - tissue velocity values in the control group and the group with CHF;

E'sep, A'sep, S'sep - E', A', S' velocities at the septal mitral annulus; E' lat, A' lat, S' lat - E', A', S' velocities at the lateral mitral annulus; E'dr, A'dr, S'dr - E', A', S' velocities at the lateral tricuspid annulus

\begin{tabular}{|c|c|c|c|c|c|c|c|c|}
\hline \multicolumn{2}{|c|}{ Descriptive parameters } & \multirow{2}{*}{$\mathbf{N}$} & \multirow{2}{*}{ Mean } & \multirow{2}{*}{$\begin{array}{l}\text { Standard } \\
\text { deviation }\end{array}$} & \multicolumn{2}{|c|}{$95 \%$ mean confidence interval } & \multirow{2}{*}{ Minimum } & \multirow{2}{*}{ Maximum } \\
\hline & & & & & Lower bound & Upper bound & & \\
\hline \multirow{3}{*}{ E' lat } & C.G. & 18 & 16.97 & 3.71 & 15.13 & 18.82 & 10.2 & 23.9 \\
\hline & S.G. & 9 & 10.12 & 1.35 & 9.09 & 11.16 & 9.2 & 13.4 \\
\hline & Total & 27 & 14.69 & 4.52 & 12.90 & 16.48 & 9.2 & 23.9 \\
\hline \multirow{3}{*}{ A' lat } & C.G. & 18 & 5.75 & 1.49 & 5.01 & 6.49 & 3.9 & 9.6 \\
\hline & S.G. & 9 & 4.80 & 0.42 & 4.48 & 5.12 & 4.1 & 5.4 \\
\hline & Total & 27 & 5.44 & 1.31 & 4.92 & 5.95 & 3.9 & 9.6 \\
\hline \multirow{3}{*}{ S' lat } & C.G. & 18 & 9.93 & 2.64 & 8.62 & 11.24 & 5.8 & 15.1 \\
\hline & S.G. & 9 & 7.73 & 0.57 & 7.29 & 8.17 & 7.1 & 8.7 \\
\hline & Total & 27 & 9.20 & 2.40 & 8.25 & 10.15 & 5.8 & 15.1 \\
\hline \multirow{3}{*}{ E' sep } & C.G. & 18 & 12.97 & 2.19 & 11.88 & 14.06 & 9.1 & 16.4 \\
\hline & S.G. & 9 & 7.51 & 2.87 & 5.30 & 9.72 & 4.2 & 10.9 \\
\hline & Total & 27 & 11.15 & 3.54 & 9.75 & 12.55 & 4.2 & 16.4 \\
\hline \multirow{3}{*}{$A^{\prime}$ sep } & C.G. & 18 & 5.78 & 2.18 & 4.69 & 6.86 & 0.1 & 8.2 \\
\hline & S.G. & 9 & 6.23 & 0.69 & 5.70 & 6.77 & 5.2 & 7.5 \\
\hline & Total & 27 & 5.93 & 1.82 & 5.21 & 6.65 & 0.1 & 8.2 \\
\hline \multirow{3}{*}{ S' sep } & C.G. & 18 & 8.38 & 1.01 & 7.87 & 8.88 & 6.5 & 10.2 \\
\hline & S.G. & 9 & 6.79 & 0.41 & 6.48 & 7.10 & 6.4 & 7.6 \\
\hline & Total & 27 & 7.85 & 1.14 & 7.40 & 8.30 & 6.4 & 10.2 \\
\hline \multirow{3}{*}{$E^{\prime} d r$} & C.G. & 18 & 12.83 & 1.78 & 11.94 & 13.71 & 8.8 & 15 \\
\hline & S.G. & 9 & 8.97 & 1.04 & 8.17 & 9.77 & 8.2 & 11.6 \\
\hline & Total & 27 & 11.54 & 2.42 & 10.58 & 12.50 & 8.2 & 15 \\
\hline \multirow{3}{*}{$A^{\prime} d r$} & C.G. & 18 & 8.07 & 1.74 & 7.21 & 8.94 & 5.2 & 12.8 \\
\hline & S.G. & 9 & 8.07 & 1.58 & 6.85 & 9.28 & 6.3 & 10.7 \\
\hline & Total & 27 & 8.07 & 1.66 & 7.42 & 8.73 & 5.2 & 12.8 \\
\hline \multirow{3}{*}{$S^{\prime} d r$} & C.G. & 18 & 12.23 & 2.99 & 10.75 & 13.72 & 5 & 20 \\
\hline & S.G. & 9 & 8.91 & 1.97 & 7.40 & 10.43 & 6.7 & 10.9 \\
\hline & Total & 27 & 11.13 & 3.10 & 9.90 & 12.35 & 5 & 20 \\
\hline
\end{tabular}

Legend: C.G. = control group; S.G. = study group. 
Table 7

Student test - evaluation of the statistical significance of tissue velocities E'sep, A'sep, S'sep - (E', A', S' velocities at the septal mitral annulus), E' lat, A' lat, $S^{\prime}$ lat (E', A', S' velocities at the lateral mitral annulus), E'dr, A'dr, S'dr (E', A', S' velocities at the lateral tricuspid annulus)

\begin{tabular}{|c|c|c|c|c|c|c|c|c|c|c|}
\hline \multicolumn{11}{|c|}{ Independent groups } \\
\hline & & \multicolumn{2}{|c|}{$\begin{array}{c}\text { Levene's test for } \\
\text { the equality of } \\
\text { variances }\end{array}$} & \multicolumn{7}{|c|}{ t-test for the equality of means } \\
\hline & & \multirow{2}{*}{$\mathbf{F}$} & \multirow{2}{*}{$\mathbf{P}$} & \multirow{2}{*}{$\mathbf{t}$} & \multirow{2}{*}{ df } & \multirow{2}{*}{$\mathbf{p}$} & \multirow{2}{*}{ M.D. } & \multirow{2}{*}{$\begin{array}{l}\text { S.E. } \\
\text { M.D. }\end{array}$} & \multicolumn{2}{|c|}{$\begin{array}{l}95 \% \text { mean difference } \\
\text { confidence interval }\end{array}$} \\
\hline & & & & & & & & & $\begin{array}{l}\text { Lower } \\
\text { bound }\end{array}$ & $\begin{array}{l}\text { Upper } \\
\text { bound }\end{array}$ \\
\hline E' lat & Unequal variances & 5.91 & 0.02 & 6.96 & 23.65 & $<0.01$ & 6.85 & 0.98 & 4.82 & 8.88 \\
\hline$A^{\prime}$ lat & Unequal variances & 6.74 & 0.02 & 2.52 & 21.70 & 0.02 & 0.95 & 0.38 & 0.17 & 1.74 \\
\hline$S^{\prime}$ lat & Unequal variances & 12.94 & 0.00 & 3.38 & 20.00 & $<0.01$ & 2.20 & 0.65 & 0.84 & 3.56 \\
\hline E' sep & Equal variances & 4.24 & 0.05 & 5.50 & 25.00 & $<0.01$ & 5.46 & 0.99 & 3.41 & 7.50 \\
\hline A' sep & Equal variances & 2.26 & 0.15 & -0.61 & 25.00 & 0.55 & -0.46 & 0.75 & -2.00 & 1.09 \\
\hline$S^{\prime}$ sep & Unequal variances & 5.89 & 0.02 & 5.79 & 24.40 & $<0.01$ & 1.59 & 0.27 & 1.02 & 2.15 \\
\hline$E^{\prime} \mathrm{dr}$ & Equal variances & 4.37 & 0.05 & 5.97 & 25.00 & $<0.01$ & 3.86 & 0.65 & 2.53 & 5.19 \\
\hline$A^{\prime} d r$ & Equal variances & 0.26 & 0.62 & 0.01 & 25.00 & 0.99 & 0.01 & 0.69 & -1.41 & 1.42 \\
\hline$S^{\prime} \mathrm{dr}$ & Equal variances & 0.05 & 0.83 & 3.01 & 25.00 & 0.01 & 3.32 & 1.11 & 1.05 & 5.60 \\
\hline
\end{tabular}

Legend: M.D. = mean of differences; S.E. $=$ standard error.

\section{DISCUSSION}

The correlation between standard parameters and tissue Doppler parameters for the measurement of the global systolic and diastolic ventricular function in both healthy pediatric patients and patients with CHF was also emphasized in this study. Some conventional parameters of the diastolic function were maintained within normal or pseudonormal values in patients with heart failure, the diastolic dysfunction being confirmed in these cases by TDI measurements and their correlation. A decrease in $\mathrm{Vp}$ and $\mathrm{E}$ velocity, as well as a significant increase in EDT in patients diagnosed with heart failure were found, which shows the reliability of these parameters in the evaluation and quantification of left ventricular diastolic dysfunction in children. Tissue Doppler velocities underwent significant changes in patients with heart failure, the systolic and diastolic dysfunction assessed by standard echocardiographic measurements (2D, $\mathrm{M}$ mode, Doppler) being confirmed by tissue Doppler parameters. This also certifies the validity and reproducibility of tissue Doppler velocities in clinical practice.

Studies of the atrial and ventricular filling pattern in children have identified variable models of diastolic transmitral and pulmonary venous flow, which seem to correlate with age. The greatest changes in the diastolic pattern occur in newborns and infants, when ventricular filling predominantly occurs during atrial contraction, evidencing in this way a low $\mathrm{E}$ velocity and E/A ratio. Thus, this pattern is equivalent to the altered relaxation or low compliance pattern. The transvenous pulmonary Doppler flow is also changed in young infants, evidencing high systolic velocities, low diastolic velocities and a high ratio between systolic and diastolic velocity compared to those found in older children. These changes that occur in the neonatal/ infant period seem to reflect the differences in the diastolic properties of the immature myocardium [16]. At birth, the left ventricular relaxation properties seem to be severely affected, which is reflected by a prolongation of the isovolumic relaxation time and a limited rapid transmitral filling flow, diastolic filling predominantly occurring during atrial contraction [17, 18]. This pattern undergoes rapid changes during the first two months of life, after which changes become significantly slower. Similar changes were seen in the case of the transtricuspid flow in newborns [19]. TDI parameters at the level of the mitral annulus seem to follow the same pattern in the newborn, but the tissue velocities seem to return to normal within 7 days of life [20]. In contrast, tissue velocities at the tricuspid annulus undergo no changes, which suggests a different adaptation of the right ventricle compared to the left ventricle. These changes progressively disappear with age, the diastolic pattern becoming similar to that found in adults. 
Some studies performed in children with congenital heart disease associated with a chronic increase in LV preload have shown minimal changes in TDI velocities compared to those measured in healthy children [21].

Previous tissue Doppler studies in adults have also shown that LV tissue velocities have a predictive value of survival in patients with $\mathrm{CHF}$ [3]. Vassalos et al. evaluated ventricular function changes measured by TDI parameters in 35 pediatric patients with congenital heart disease after repair surgery. The authors found a significant postoperative decrease in TDI velocities, a reduction of right ventricular TDI velocities associated with the degree of extension of myocardial injury measured by troponin I level, and an association between the low value of left ventricular TDI velocities and the increase in the duration of ventilation in intensive care. This might have a predictive value in the determination of postoperative evolution, as well as in the optimal timing of repair surgery for congenital heart malformations [22]. In certain cases, TDI allows a better evaluation of the RV, being a more sensitive method than serum BNP level and the ejection fraction [23]. TDI has recently shown that the abnormal ejection prefraction and subclinical systolic dysfunction can coexist with diastolic dysfunction in children with restrictive cardiomyopathy [24].

Kiraly et al. studied 24 children with congenital aortic stenosis, demonstrating a significant decrease in longitudinal systolic and diastolic tissue velocities at the level of the posterior and lateral left ventricular walls [25]. Eidem et al. reported a series of 96 children with various degrees of congenital aortic stenosis and showed a significant decrease in early and late systolic and diastolic tissue velocities at the septal and lateral mitral annulus, the systolic-diastolic function parameters measured by standard methods being within normal limits. The patients with the highest transaortic gradients had the most significant decreases in tissue velocities, suggesting that postload influences to a great extent these tissue velocities [26]. Pauliks et al. evaluated 39 children with atrial septal defect both before and after the percutaneous repair of the defect, demonstrating a transient decrease of tissue velocities in all myocardial segments, which returned to normal after 24 hours. This might suggest a relative dependence of tissue velocities on ventricular filling conditions in this category of patients [27]. Other studies have suggested the fact that the relative dependence of tissue velocities on ventricular filling conditions in children with atrial septal defect is influenced by right ventricular size and compliance [28]. Tissue velocities were also studied in patients with the tetralogy of Fallot, showing a decrease after surgical correction and being correlated with the degree of pulmonary insufficiency [29]. The right ventricular reserve also proved to be low in these patients during submaximal exercise, being correlated with the decrease of tissue velocities at the tricuspid annulus, with the degree of pulmonary insufficiency, as well as with high atrial natriuretic peptide levels [30].

Tissue Doppler echocardiography also proved to be useful in other diseases.

McMahon et al. performed standard echocardiographic and TDI studies in children with dilated cardiomyopathy and in those with hypertrophic cardiomyopathy, in order to determine the predictors of adverse clinical events (defined as death, heart transplantation or hospitalization). In children with dilated cardiomyopathy, only early diastolic velocity at the tricuspid annulus Ea $<$ $8.5 \mathrm{~cm} / \mathrm{sec}$ and LVEF $<30 \%$ represented negative prognostic predictors in multivariate analysis [31]. In children with hypertrophic cardiomyopathy, the septal E/Ea ratio proved to be a significant unfavorable prognostic predictor [32]. Other studies have shown the utility of TDI parameters in the early identification of heart transplantation rejection in pediatric patients $[33,34]$. The applicability of tissue Doppler extends to the evaluation of early and late cardiotoxic effects of anthracyclines in pediatric oncologic patients $[35,36]$.

However, as future research directions, studies should focus on the limitations of the TDI method [37] in general: the dependence on the interrogation angle, the difficulty in examining all segments, the influence of the translation movement and the impossibility to exclude the passive movement of the heart. The literature reports that the limitations determined by the translation movement and the passive movements of the heart are eliminated by myocardial strain rate imaging [38].

\section{CONCLUSIONS}

In children with heart failure, some conventional diastolic function parameters were maintained within normal or pseudonormal values, diastolic dysfunction being confirmed in these cases by TDI measurements. 
Among conventional parameters, EDT and $\mathrm{Vp}$ were noted, which underwent changes in the sense of a significant increase and decrease, respectively, in patients with heart failure.

In pediatric $\mathrm{CHF}$ secondary to congenital heart malformations, a decrease in systolic and diastolic TDI parameters is found.

Tissue Doppler imaging can be used both independently and in association with conventional echocardiographic parameters for the confirmation or the diagnosis of systolic-diastolic dysfunction in children.

Acknowledgements. This study was financed by the Government grant CNCSISPNII-IDEI, code 1147/2008.

Conflict of interest: The authors declared no conflicts of interest to this article.

Introducere. Ecocardiografia bidimensională (2D) şi examinarea Doppler sunt principalele metode pentru evaluarea non-invazivă a funcției ventriculare la copii. Studiul nostru a monitorizat evaluarea funcției sistolice şi diastolice la copii, folosind parametrii clasici ecocardiografici şi parametrii Doppler tisular pulsat, precum şi corelația dintre aceştia.

Metode. Studiul a inclus 18 copii sănătoşi şi 9 copii diagnosticați cu insuficiență cardiacă congestivă secundară malformațiilor cardiace congenitale. Parametrii funcției sistolice şi diastolice au fost măsurați prin ecocardiografie $2 D$, in mod $M$ ghidat 2D, Doppler color şi pulsat, precum şi prin Doppler tisular pulsat la nivelul inelului mitral şi tricuspidian.

Rezultate. Un pattern de relaxare alterare sau un pattern pseudonormal al vitezei $E$ diastolice comparativ cu unda A a fost găsit $(E=A ; E>A)$ in grupul de subiecți cu insuficiență cardiacă. Timpul de decelerare al undei $E$ a avut valori semnificativ crescute în cazul pacienților cu insuficiență cardiacă congestivă, fiind corelate cu disfuncția diastolică. Viteza de propagare ventriculară stângă a fluxului Vp a fost scăzută la pacienții cu insuficiență cardiacă, raportul E / Vp fiind menținut relativ constant la subiecții cu insuficiență cardiacă congestivă secundară şi subiecții sănătoşi, cel mai probabil din cauza schimbării concomitent în unda E. Asociații între severitatea disfuncției sistolice şi disfuncției diastolice au fost găsite la copiii diagnosticați cu insuficiență cardiacă congestivă (testul Student, $p<0.05$ ).

Concluzii. Măsurătorile Doppler tisular s-au dovedit a fi utile pentru evaluarea copiilor cu geometrie ventriculară alterată secundară la bolile cardiace congenitale, disfuncția sistolică-diastolică şi insuficiența cardiacă.

Correspondence to: Gabriel SAMASCA, PhD, Department of Immunology - 19-21 Croitorilor Street,

"Iuliu Hațieganu" University of Medicine and Pharmacy Cluj-Napoca, Romania, Tel: +40264532216 ,

E-mail: Gabriel.Samasca@umfcluj.ro

\section{REFERENCES}

1. LANG R, BIERIG M, DEVEREUX R. Recommendations for chamber quantifications. Eur J Echocardiogr. 2006; 7:79-108.

2. WILLENHEIMER R, CLINE C, ERHARDT L, ISRAELSSON B. Left ventricular atrioventricular plane displacement: an echocardiographic technique for rapid assessment of prognosis in heart failure. Heart. 1997; 78:230-6.

3. $\mathrm{OH} \mathrm{JK}$, APPLETON CP, HATLE LK, et al. The non-invasive assessment of left ventricular diastolic function with twodimensional and Doppler echocardiography. J Am Soc Echocardiog. 1997; 10:246-70.

4. GARCIA MJ, SMEDIRA NG, GREENBERG NL. Color M-mode Doppler inflow propagation velocity is a preload insensitive index of left ventricular relaxation: animal and human validation. J Am Coll Cardiol. 2000; 35:201-8.

5. LAI WW, MERTENS LL, COHEN MS, GEVA T. Echocardiography in pediatric and congenital heart disease from fetus to adult, 2009, Wiley-Blackwell, 76-116. 
6. EIDEM BW, MCMAHON CJ, COHEN RR. Impact of cardiac growth on Doppler tissue imaging velocities: a study in healthy children. J Am Soc Echocardiogr. 2004; 17:212-21.

7. KUKULSKI T, WILKENSHOFF UM, STROTMANN JM, WRANNE B, HATLE L, SUTHERLAND GR. A comparison of regional myocardial velocity information derived by either pulsed or colour Doppler techniques. An in vitro and in vivo study. Echocardiography. 2000; 17:639-51.

8. WILLENHEIMER R, CLINE C, ERHARDT L, ISRAELSSON B. Left ventricular atrioventricular plane displacement: an echocardiographic technique for rapid assessment of prognosis in heart failure. Heart. 1997; 78:230-6.

9. HENEIM M, GIBSON D. Normal long axis function. Heart. 1999; 81:111-3.

10. EIDEM BW, MCMAHON CJ, AYRES NA. Impact of chronic left ventricular preload and afterload on Doppler tissue imaging velocities; a study in congenital heart disease. J Am Soc Echocardiog. 2005; 18:830-8.

11. FROMMELT PC, BALLWEG JA, WHITSTONE BN. Usefulness of Doppler tissue imaging analysis of tricuspid annular motion for determination of right ventricular function in normal infants and children. Am J Cardiol. 2002; 89:610-3.

12. LINDSTROM L, WRANNE B. Pulsed tissue doppler evaluation of mitral annulus motion: a new window to assessment of diastolic function. Clin Physiol 1999; 19:1-10.

13. Pascotto M, Caso P, Santoro G, Casa I, Cerrato F, Pisacane C, et al. Analysis of right ventricular Doppler tissue imaging and load dependence in patients undergoing percutaneous closure of atrial septal defect. Am J Cardiol 2004; 94:1202-5.

14. EIDEM BW, MCMAHON CJ, COHEN RR. Impact of cardiac growth on Doppler tissue imaging velocities: a study in healthy children. J Am Soc Echocardiogr 2004; 17:212-21.

15. ALAM M, WARDELL J, ANDERSSON E, SAMAD B, NORDLANDER R. Right ventricular function in patients with inferior myocardial infarction: assessment by tricuspid annular motion and tricuspid annular velocity. Am Heart J 2000; 22:710-5.

16. Lai WW, Mertens LL, Cohen MS, Geva T. Echocardiography in pediatric and congenital heart disease from fetus to adult, 2009.

17. SCHMITZ L, XANTHOPOULOS A, KICH H. Doppler flow parameters of left ventricular filling in infants: how long does it take for the maturation of the diastolic function in a normal left ventricle to occur? Pediatr Cardiol 2005; 75:24-9.

18. SCHMITZ L, XANTHOPOULOS A, LANGE PE. Isovolumic relaxation time shortens significantly during three months after birth. J Am Soc Echocardiogr 2004; 17:275-6.

19. RIGGS TW, RODRIGUEZ R, SNIDER AR. Doppler echocardiographic evaluation of right and left ventricular filling in normal neonates. J Am Coll Cardiol 1989; 13:700-5.

20. MORI K, NAKAWA M, EDAGAWA T. Pulsed wave Doppler tissue echocardiography assessment of the long axis function of the right and left ventricles during the early neonatal period. Heart 2004; 90:175-80.

21. HARADA K, TAMURA M, KYASUOKA, TOYONO M. A comparison of tissue doppler imaging and velocities of transmitral flow in children with elevated left ventricular preload. Cardio Young 2001; 11:261-268.

22. Vassalos A, Lilley S, Young D, Peng E, MacArthur K, Pollok J, et al. Tissue Doppler imaging following paediatric cardiac surgery: early patterns of change and relationship to outcome. Interact Cardiovasc and Thoracic Surg 2009; 20171723: 1-5.

23. RO PS, CHAN DP, ACKLEY T, FENSTERMAKER B, HAYES J, CUA CL. Tissue doppler changes in pediatric complete heart block patients who are chronically paced. Congenit Heart Dis 2009; 4(6):448-53.

24. SASAKI N, GARCIA M, LYTRIVI I, KO H, NIELSEN J, PARNESS I, SRIVASTAVA S. Utility of Doppler tissue imagingderived indices in identifying subclinical systolic ventricular dysfunction in children with restrictive cardiomyopathy. Pediatr Cardiol 2011; 32(5):646-51.

25. KIRALY P, KAPUSTA L, THIJSSEN JM, et al. Left ventricular myocardial function in congenital valvar aortic stenosis assessed by ultrasound tissue velocity and strain-rate techniques. Ultrasound in Med Biol 2003; 29:615-620.

26. EIDEM B, MCMAHON, AYRES NA, et al. Impact of chronic left ventricular preload and afterload on doppler tissue imaging velocities A study in congenital heart disease. J Am Soc Echocardiogr 2005; 18:830-8.

27. PAULIKS LB, CHAN KC, CHANG D, et al. Regional myocardial velocities and isovolumic acceleration before and after device closure of atrial septal defects - a color tissue doppler study. Am Heart J 2005; 150:294-301.

28. PASCOTTO M, CASO P, SANTORO G, CASA I, CERRATO F, PISACANE C, et al. Analysis of right ventricular Doppler tissue imaging and load dependence in patients undergoing percutaneous closure of atrial septal defect. Am J Cardiol 2004; 94:1202-5.

29. HARADA K, TOYONO M, YAMAMOTO F. Assessment of right ventricular function during exercise with quantitative doppler tissue imaging in children late after repair of tetralogy of Fallot. Journal of the American Society of Echocardiography 2004; 17:863-9.

30. H ISHII, K HARADA, M TOYONO, M TAMURA, G TAKADA. Usefulness of exercise-induced changes in plasma levels of brain natriuretic peptide in predicting right ventricular contractile reserve after repair of tetralogy of Fallot. Am J Cardiol 2005; 95:1338-43.

31. MCMAHON CJ, NAGUEH SF, EAPEN RS, et al. Echocardiographic predictors of adverse clinical events in children with dilated cardiomyopathy a prospective clinical study. Heart 2004; 90:908-15.

32. MCMAHON CJ, NAGUEH SF, PIGNATELLI RH, et al. Characterisation of left ventricular diastolic function by tissue doppler imaging and clinical status in children with hypertrophic cardiomyopathy. Circulation 2004; 109:1756-1762.

33. FYFE DA, MAHLE WT, KANTER KR, et al. Reduction of tricuspid annular doppler tissue velocities in pediatric heart transplant patients. J Heart Lung Transplant 2003; 22:553-9. 
34. PAULIKS LB, PIETRA BA, DEGROFF CG, et al. Non-invasive detection of acute allograft rejection in children by doppler tissue imaging: myocardial acceleration during isovolumic contraction. J Heart Lung Transplant 2005; 24:S239-48.

35. KAPUSTA L, THIJSSEN JM, GROOT-LOONEN J, et al. Tissue doppler imaging in detection of myocardial dysfunction in survivors of childhood cancer treated with anthracyclines. Ultrasound in Med Biol 2000; 26:1099-108.

36. KAPUSTA L, GROOT-LOONEN J, THIJSSEN JM, et al. Regional cardiac wall motion abnormalities during and shortly after anthracyclines therapy. Med Pediatr Oncol 2003; 41:426-435.

37. LUERS C, MAISCH B. Echocardiography: future developments. What is diastole and how to assess it? Impaired left ventricular systolic function. Minerva Cardioangiol. 2011; 59(4):331-48.

38. SUTHERLAND GR, HATlE L, ClAUS P, D’HOOGE J, BIJNENS BH. Doppler Myocardial Imaging. Pediatric and congenital heart disease 2006; 325-43.

Received August 11, 2015 